


\section{DISCLAIMER}

This report was prepared as an account of work sponsored by an agency of the United States Government. Neither the United States Government nor any agency Thereof, nor any of their employees, makes any warranty, express or implied, or assumes any legal liability or responsibility for the accuracy, completeness, or usefulness of any information, apparatus, product, or process disclosed, or represents that its use would not infringe privately owned rights. Reference herein to any specific commercial product, process, or service by trade name, trademark, manufacturer, or otherwise does not necessarily constitute or imply its endorsement, recommendation, or favoring by the United States Government or any agency thereof. The views and opinions of authors expressed herein do not necessarily state or reflect those of the United States Government or any agency thereof. 


\section{DISCLAIMER}

Portions of this document may be illegible in electronic image products. Images are produced from the best available original document. 
Irradiated fure 1 is received at the plant either by truck or rail. The plant is capable of receiving and handling LWR fuel as long as $16 \mathrm{ft}$. and 6 in. square. Irradiated fuel is cooled for a minimum of 150 days from reactor discharge prior to reprocessing. When scheduled for reprocessing, fuel is transferred to a mechanical cell where the end hardware is removed by a remotely operated saw. The prepared fuel element is loaded into the shear magazine, where it is pushed, by a ram, into the shear. The shear is a 300-ton hydraulic unit in which the fuel can be sheared into pieces ranging in length from $1 / 2$ to $2 \mathrm{in.}$ The sheared pieces fall into a chute and are collected in chopped fuel canisters.

The chopped fuel canisters are perforated boron-stainless stee 1 cylinders $8 \mathrm{in.}$. ID by $7 \mathrm{ft}$. high. Because shearing disintegrates much of the fuel into powder, the canisters are fitted with consumable thin-wall mild stee 1 liners.

The NFS dissolver design is somewhat unique. Its design was complicated by the fact that it had to be capable of handling fuel of widely varying composition and enrichment. It consists of a lower $3 \mathrm{in.} \mathrm{annulus}$ which contains six $10 \mathrm{in}$. ID barrels which accept the 8 in. fuel baskets. This portion of the vessel sits down over a boron-containing concrete core which serves to isolate each barrel position from the others. The top of the annulus connects with a full diameter surge tank which contains the amount of dissolvent necessary to produce a final fuel concentration which will be critically safe under all conditions.

Off-gas from the dissolver is treated by passage through a downdraft condenser, a secondary condenser, a scrubber, iodine removal by absorption on a chemical trap, and filtration through high-efficiency particulate air filters. The filtered discharge is exhausted through a 63-meter stack. This stream includes the chemically inert but radioactive species of krypton, and a portion of the tritium initially contained in the fue 1.

Fuel solution from the dissolver is transferred to a feed adjustment and accountability tank. The leached hulls are rinsed with water, and this rinse liquid is added to the fuel solution. After the hulls have dried they are inspected and sampled to determine what losses may have been experienced, afier which they are buried as solid waste.

The volume of the fuel solution in the accountability tank is measured accurately and sampled for analysis. This analys is represents the feed input to the system and establishes the financial accountability of the plant.

The recovery and decontamination of uranium and plutonium from the fue 1 solution is accomplished by a Purex solvent extraction process in which the solvent is tributyl phosphate dissolved in n-dodecane. Pulse column contactors are used. The first cycle is a partition cycle in which uranium and plutonium are separated from each other and from $99.9+\%$ of the fission products. Two additional cycles of solvent extraction are used to complete the purification of the uranium product. The plutonium product is processed through one additional solvent extraction cycle, followed by anion exchange treatment to achieve final purification and concentration; it is then further concentrated in a titanium evaporator and transferred to bottles for shipment. 
The acid waste streams are evaporated to concentrate them for storage, to decontaminate the excess 1 iquid, and to recover nitric acid for recycle. The principle process off-gases from the operating vessels are contained in treatment systems designed to remove radioactivity and are subsequently discharged with process building exhaust gases to the atmosphere through a high efficiency filtration system.

The high-level radioactive waste concentrate is neutralized and stored in 750,000-gal. waste tanks that are buried underground. These liquid wastes will eventually be converted to stable solids for ultimate disposal.

The NFS plant has now been in operation for almost $5 \frac{1}{2}$ years and has processed about 700 tonnes of irradiated fuel. The most highly irradiated fuel processed to date was irradiated to a burnup of $22,500 \mathrm{MWD} / \mathrm{T}$ and cooled 9 months.

In general, performance of the plant has been very good. Recovery of fissile materials has been in excess of $98.5 \%$, decontamination of uranium and plutonium from fission products has been satisfactory, and in-specification products are produced routinely. The plant consistently has met all federal regulations for the release of gaseous and liquid radioactive wastes to the environs.

The performance of the shear has also been good. As the first unit in hot operation, some design modifications and repajrs have been necessary, but these were accomplished remotely without excessive downtime.

The existence of some design deficiencies in the plant, mainly in the acid recovery and ventilation systems, was encountered. Two filters in the off-gas system failed, releasing some activity to the environs. In neither case was the release near the maximum permissible level. In addition, the routing of certain off-gas lines created radiation fields in certajn work areas. Corrective measures have been taken to resolve these problems.

Modifications to the plant are currently in progress which will increase the capacity for reprocessing LWR fuels from the design rate of $1 \mathrm{MTU} /$ day to 2-3 MTU/day. Future planned modifications include the addition of facilities to convert $\mathrm{Pu}\left(\mathrm{NO}_{3}\right)_{4}$ to $\mathrm{PuO}_{2}$, uranium nitrate hexahydrate (UNH) to $\mathrm{UF}_{6}$, and liquid waste (high level) to solid form.

\section{Midwest Fue 1 Recovery Plant}

Construction of General Electric's Midwest Fuel Recovery Plant (MFRP) at Morris, Illinois has been completed, and cold shakedown operations are in progress. The plant has an initial capacity of $1 \mathrm{MTU} /$ day to recover uranium, plutonium and neptunium from LWR fuels originally enriched to about $5 \%$ in U-235 or equivalent plutonium reactivity. Figure 1 is a simplified block diagram of the patented Aquafluor (1) process which is summarized below. 


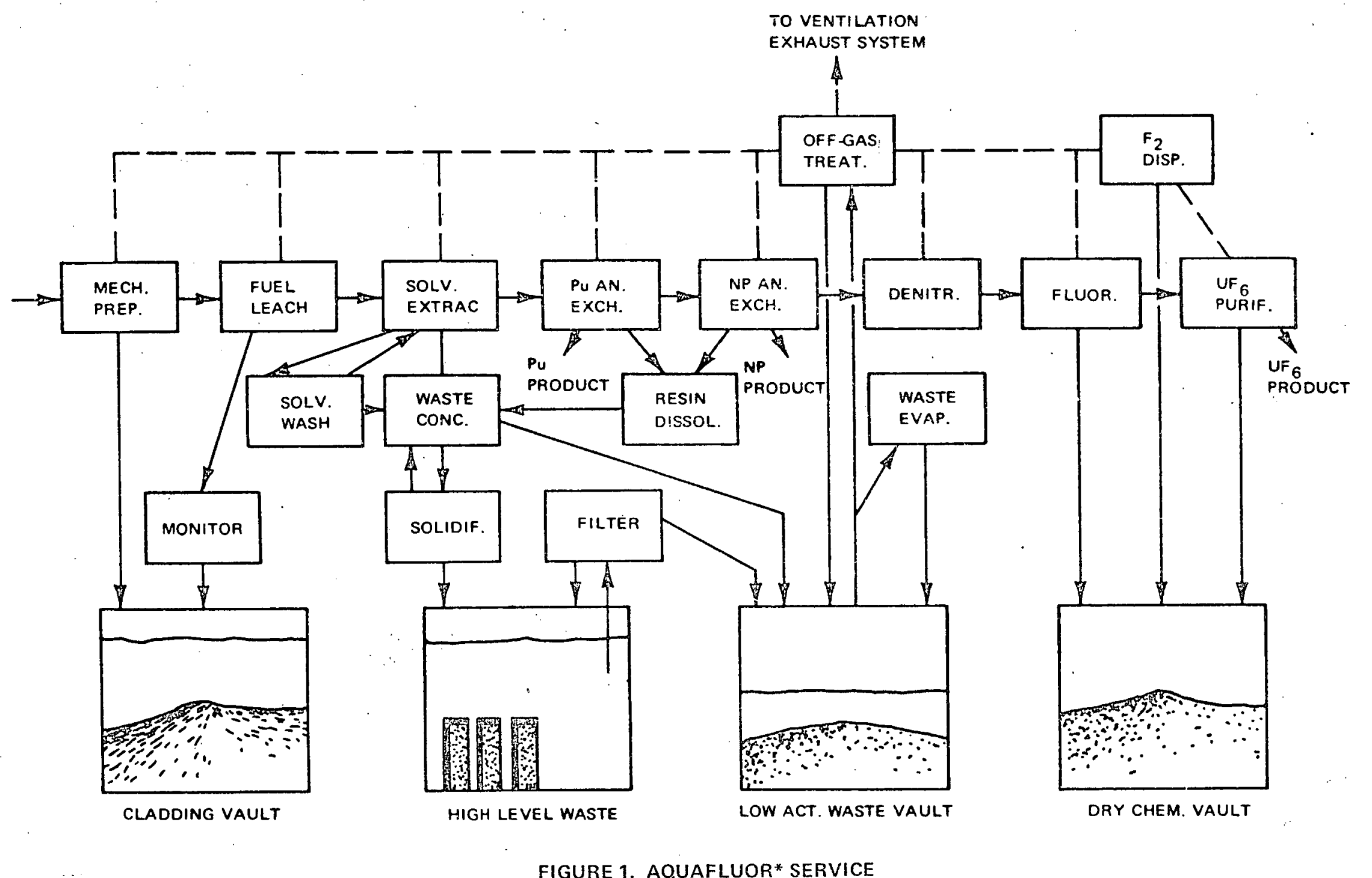

*Service Mark of the General Electric Company 
Feed preparation is by mechanical disassembly of the as-received fue 1 after which the fuel rods are sheared into short lengths and fed into a dissolver. The fuel, containing the plutonium, neptunium and fission products formed during ixradiation as well as the unspent uranium is leached out of the cladding hulls with nitric acid. After fuel dissolution, the cladding hulls are conveyed to a storage area of capacity appropriate to long range plant needs.

Initial separation of the fuel constituents of economic interest from 99.9+\% of the highly radioactive fission products is by a single, co-decontamination solvent extraction cycle of the Purex type. The high activity waste stream which results from this operation is reduced to a small volume of dry, inert solids for retention in cooling basins provided as part of the plant facilities. Solvent degradation products resulting from the highly radioactive environment are washed from the solvent and routed to the high activity waste disposal system provided for the plant.

Recovery and final decontamination of plutonium and neptunium are accomplished by anion exchange, after which the recovered products are concentrated and then routed to loading facilities in the form of nitrate solutions. Spent resins -- caused either by chemical or radiolytic degradation -- are sent to the high activity waste handling system for disposal.

The uranium process stream coming from the ion exchange operation is fed to an intercycle concentrator to form a UNH solution suitable for the subsequent calcination operation. Conversion of the $\mathrm{UNH}_{\mathrm{NO}} \mathrm{UO}_{3}$ is acconplished by means of a fluidized bed calciner. Particulate vO3 which is elutriated from the calciner is routed to a fines recovery tower wherein the $\mathrm{UO}_{3}$ is dissolved in nitric acid and subsequently recycled to the UNH concentrator for uranium recovery. Finally, the $\mathrm{UO}_{3}$ is reacted with elemental fluorine to form UF6 in a fludized bed fluorinator. The inert bed material used $i r_{1}$ the fluorinator (fused alumina) periodically will be disposed of to the low level waste disposal system. Final purification of the UF6 from traces of plutonium, neptunium and certain fission products is accomplished by passing the gaseous $\mathrm{UF}_{6}$ through $\mathrm{NaF}$ and $\mathrm{MgF}_{2}$ beds followed by distillation of liquid $\mathrm{UF}_{6}$.

A disposal system is provided for high activity wastes (i.e., those wastes which are both radioactively and thermally "hot") in which the waste streams are concentrated, reduced to solid form, and packaged in high integrity containers so that they can be submerged in a water filled basin for on-site retention prior to shipment to an AEC repository.

A low activity waste disposal system is provided which includes liquid concentration equipment and an underground storage vault in which the radioactive material sets up as a salt cake, on cooling, for immoblized on-site retention. Gaseous waste streams from the process are all filtered, scrubbed, and monitored prior to release from the plant ventilation stack. There are no radioactive liquid effluents from the GE recovery plant. 


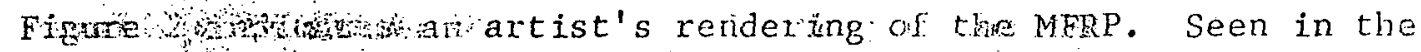

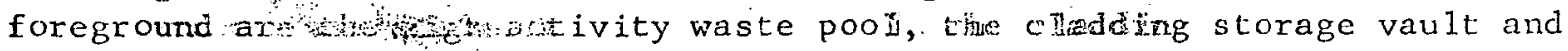
the low activity wase whlt. Indicated are the wewald cell where the fuel is disassembled anthopped into sma11 prisees, frow which the core material is leached, an the main process camyon andeat. On the right hand side toward the center of the picture is the simbl filititer through which all the ventilation air is filtered prior to dissdiar tse throagh the stack.

The measurement techniques to be usedi $\forall y r$ the reprocessor are important in accounting for the valuable materials whibh are betime recovered. General Electric has chosen to base the uranium inpuit to the resovery plant on the weight of uranium as originally fabricated: andl charged into the reactor. The fuel fabricator's certified weight of unamim iis adjusted for burnup and transmutation based on mass ratio analyssis\%. Fine wainty in this gravimetric method is about $0.22 \%$ as compased to the approximate $1 y 0.75 \%$ associated with the alternate volumetric taxhmigue. The plutonium input is determined by multiplying the uranium innut by the plitonium to uranium ratio. The output uranium and output plutiansim are oxised on direct measurements using weighing techniques.

General Electric considers transportation of the frradiated fuel from the reactor to the reprocessing plant to the: a ke.y component of fuel recovery service. General Electric has designed slinping casks for the spent fuel and their design and other transportation canciderations are discussed by C. W. Smith, et a $1^{(2)}$.

Barnwe 11 Nuclear Fue 1 Plant of Allied-Gilf Niuc Iear Services

The Barnwel1 Nuclear Fuel Plant (BNFW) of Allied (ralf Nuclear Services is designed specifically to process irradiated fuells fron LWR plants. The plant, with a design capacity of $5 \mathrm{MTU} / \mathrm{day}$; is lecuted on a 1700 acre site near Barnwe11, South Carolina at the eastem boundary of the AEC Savannah River Plant. The location permits receipt. of: fuel by highway and rail as we 11 as water shipments via the Savannah River. The Construction Permit for the plant was granted by the AEC in December 1970. Construction commenced early this year, and cold start-up will be initiated in 1973 .

Paramount considerations in the desigm afi the plant have been the safety of the workers, the safety of the general pubilite and the protection of the environment. No radioactive materials will be: added to the cooling water discharged from the plant to local water courses. Relizbility of operation was also of key importance in selection of: the proces: and design of equipment. To assure its customers of on-time dedilivery of recovered products as well as for the plant to be economical, it must be able to maintain a high on-stream capability, at an optimum capitanl cost, performing as designed. The plant is capable of receiving INR fuel: $20 \mathrm{ng}$ as $20 \mathrm{ft}$. overal1 and $11 \frac{3}{2}$ in. square; enriched to $5 \%$ U-235 prior to irraditiation, or equivalent reactivity with recycle plutonium; burnups cre up to 40,000 MWD/T; and - exposure to power densities as high as 50 mefyrgat per ton. The plant will be able to recover uranium and plutonium as nyitsates, or uranium as the hexafluoride and plutonium as the oxide. In axdition, provisions have been

(2) Smith, C.W., et al "Simipment of Imradiated Power Reactor Fuel in the United States" 


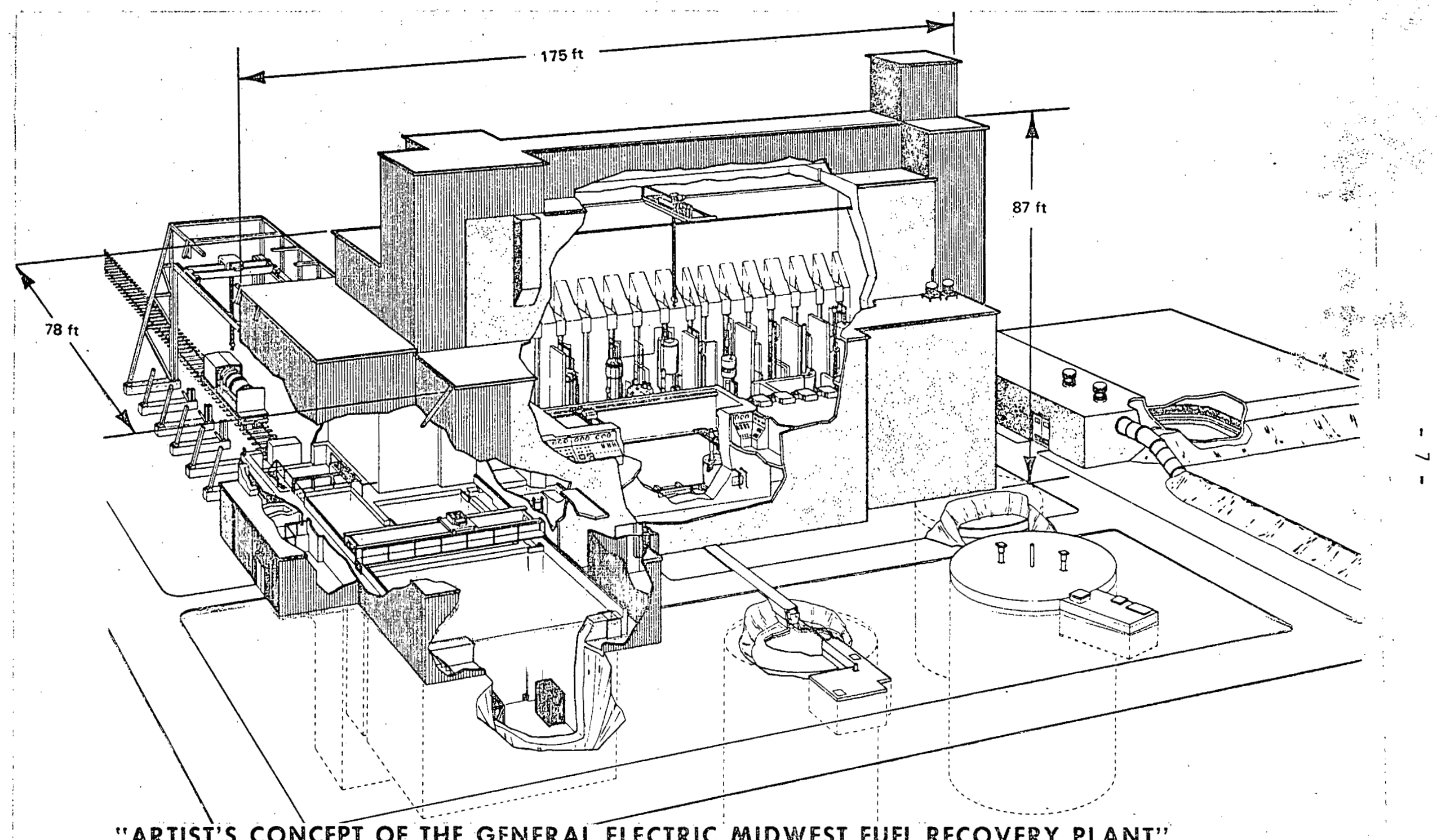

"ARTIST'S CONCEPT OF THE GENERAL ELECTRIC MIDWEST FUEL RECOVERY PLANT" FIGURE 2. 
made to allow neptunium or other potentially valuable by-products to be recovered if desired. The high plant capacity will make possible timely availability of recovered products for use in recycle fuel.

Accountability of special nuclear material has been given a high priority in equipment design and in the establishment of operating techniques. To assure the highest level of special nuclear material safeguards, AlliedGulf has elected to base input measurements on methods which are independent of fabrication.

While the process employed in the BNFP will be essentially the classical Purex solvent extraction process using a shear-leach headend system, certain unique features of process and plant design have been incorporated. These are briefly discussed as follows:

1. The plant was designed with considerable flexibility in the fue 1 receiving and handling areas. This was necessary to allow accommodation of the many fuel casks which must be handed every day to supply this large plant. In addition, the design incorpates a capability to safely handle any leaking fuel. elements which might be received.

2. The shear used in the BNFP is of unusual design in that it has capability to shear fuel without prior disassembly of fuel elements and fittings. Grids and other items of hardware will be chopped directly inco the dissolver. The shear will be able to accommodate the multiplicity of sizes which will come from reactors of varying generations and different manufacturers. It is designed to confine dust resulting from the shearing operation so that there will not be gross contamination of the process cell. Tt is also designed for ready maintenance. The shearing-dissolution system is sized for operation at a capacity substantially in excess of the plant's five tonne per day rate to allow for minor routine maintenance and for clean out and accountability between batches of fuel from different sources:

3. With a plant this size it was felt strongly that, for proper control of gaseous effluents, dissolution should be as continuous as is practical to minimize the peaking of any off-gas release which could not otherwise be contained. To accommodlate this requirement, the BNFP design incorporates a unique dissolver which operates in a semi-continuous mode with dissolution taking place as fuel is chopped directly into the nitric acid solution. Provision is made to insure that dissolution is taking place at the desired rate. This prevents an excess of accumulated undissolved material and uneven off-gas generation.

4. A somewhat troublesome feature of Purex processes is the addition of chemicals in various stages of the solvent extraction cycles for valence control. This addition of chemicals results in increased volumes or higher potential corrosion rates of the acidic solutions. The most commonly used reductant, ferrous sulfamate, gives, in nitric acid, the undesirable products of ferric nitrate and sulfuric acid as well as an increase in volume of stored wastes through increased salt content. To improve this step in the process, an electrolytic 
means of valence control has been developed for the BNFP. This is used both in the partitioning step, where uranium and plutonium are separated after the bulk of the fission products have been removed, and is also used in the subsequent cycles of plutonium purification. Allied-Gulf is enthusiastic about this means of valence control because of its applicability to future plants handling breeder reactor fuel with high pjutonium content.

5. It is a requirement that high activity wastes be contained with no chance of dispersion to the environs. At the BNFP, interim storage of the high activity wastes, prior to their conversion to stable solids, will be in stainless steel tanks located in massive concrete vaults which are lined with stainless steel. The plant will be equipped with spare tankage so that the contents of any tank can be transferred to another in the unlikely event that a leak should develop.

Removal of fission product heat from the wastes will be accomplished by submerged coils through which water will be circulated in a secondary circuit, with the heat ultimately being removed via exchangers through which primary cooling water will flow. The maintenance of cooling capability will be assured by provision of multiple back-up cooling water supply and alternate full capacity diese1-driven pumps.

6. Additional significant features of the plant are: (a) The maintenance philosophy includes use of both remote and contact maintenance. Arrangement of the cells is such that the contact cells are aligned adjacent to the remotely maintained cells.

(b) In addition to the cells provided for the process, the BNFP has had incorporated in it liberal areas for maintenance outside of the process cells. These facilities are shielded and equipped with master slave manipulators, power manipulators, cranes and decontamination equipment so that equipment worth salvaging can be repaired after it has been removed from the cells. (c) A series of sampling and analytical cells, adjacent to the contact cell system, house all of the remote sampling systems as well as a number of the in-line instruments which require shielding and have the likelihood of requiring reasonably frequent maintenance. Here high activity samples can also be taken and prepared for handling with minimal shielding in the laboratory areas. Considerable attention has been paid to the arrangement of the plant to provide for an efficient ventilation system as well as a system wherein personne 1 traffic can be accommodated without the need for frequent passages through areas of possible contamination.

The Barnwel1 Nuclear Fuel Plant, the first five tonne per day plant, designed solely for commercial light water reactor fuel processing, incorporates a unique combination of the Purex process and several contributing innovations. From its inception, the plant has been designed to be safe to both operator and public alike with minimal environmental impact. 
The Atlantichoschinld Reprocessing Cemuer (ARE Plant) is designed specifically to process irradiated fuels from swe plants. It will be located on a site of approximately 2500 acress jacent to the Broad River, approximately 13 miles southwest of Chester:; South Carolina. The plant will have a nominal capacity of $6 \mathrm{MTU} / \mathrm{day}$. Appliaratjom for a construction Permit was made on October 29, 1970, and plant stant-up ïs scbeduled for mid-1976.

The basic ARC Plant process functions wijll lixe conducted in a massive, high-integrity concrete structure (Process Butildingy especially designed to isolate operating personnel and the public fom radioactivity by the provision of radiation shielding and strict radiolioximal confinement. To provide additional isolation of the plant from the suvrowading environs, the principal facilities will be located near the cemiter of the site. Personnel access to the area and its facilities will the continolled.

Spent fuel assemblies from LNR-type reators; ane reveived at the Process Building by rail or truck shipment. Typicall fre lig are expected to be enriched to a maximum average of about three percent: $1-23.5$ But the plant will have the capability for processing mixed oxide (U62-Pugly fuels and higher enrichment fuels up to about five percent $\mathrm{U}-235$, ar equivialent reactivity. At the ARC Plant, the fuel assemblies are unloadedl firom the shipping casks in a water-filled poo1, where they are also stomert untiil schentuled for reprocessing.

When scheduled for reprocessing, fuell aesemilims are transferred mechanically to a. Remote Mechanical Cel1, whithin thie Prosess Building, where they are disassembled by shearing into suitablie levgrgths, e.g., one to three inches long. As they are sheared, the piecass fall into a dissolver. In the dissolver, the fuel is leached from the iirsoluble cladding with nitric acid. The residual leached hulls are 1 iffterd in baskets from the dissolver and are transported to high-integrity Hull Diisposall vaults for isolation from the surrounding environment.

The nitric acid solution of fuel is the feed fior the solvent extraction separation of uranium and plutonium from eacth other: and from fission products and other impurities. In the ARC Plant, a Elurex solvent-extraction process is used with pulse column contactors. Three cycles: of separation and purification are employed. The organic solventi is a: 30 percent solution of tributy 1. phosphate in a normal paraffin hydtacarbom diluent. The product

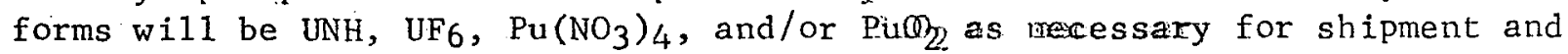
return to the nuclear fuel cycle. Provisiom has: allso been included for recovery of neptunium as a nitrate solutiom.

The spent organic solvent from the sollwean-extraction systems is continuously reclaimed for reuse in specifically digsigned organic treatment systems. Nitric acid is continuously recovened by distillation and rectification from waste concentration operations and is recycled. 
The trotmes- of liquid and gaseous streams containing radioactive waste products r. Liquid effluent systems are engineered to efffectively eliminate their radionuclide content wough the recycle of wrocess condensates to the extent practicable. The principal process offi-gases from the operating vessels are contained in treatment systems olesigned to remove radioactivity (exclusive of the krypton and tritium componemes), and are then discharged along with the Process Building ventilation calnats gases to the atmosphere through a high efficiency filtration system..

Essentially all of the fission productor are cantaned in the high level waste generated during solvent-extraction apperations. These liquid wastes are stored in vessels in a vault within the Process remiling structure. Their ultimate solidification and disposal wrill be: comsistent with Atomic Energy Commission requirements.

Recent Developments In Siting and Wartter. Management Criteria

From the time it assumed responsibility for marclear energy programs in 1946, the Atomic Energy Commission has beem aretery arare of, and concerned about, hazards associated with the highly radifoztive wastes produced in reprocessing nuclear fuels. While over 25 year of expence has been gained with the safe operation of reprocessing and related waste management facilities utilizing tank storage of liquidis: there has been a continuing concern that these long-lived wastes ultimaticely be: converted to a more stable form and isolated from man's environment for: the many thousands of years required for their radioactive decay. To timiz: emd! the AEC has conducted extensive research and development programs to cracterize the wastes and to determine the most suitable form and locaition fior ultimate disposal. Results of this research and development hawe led to the conclusion that the wastes should be solidified for transpordition to, and containment in, selected deep geologic formations, such as thed salt, for long-term storage.

The increasing acceptance of nuclear reactors by the U.S. power utility industry, and the projected requirement for more and larger capacity fuel reprocessing plants led the AEC several years ago to consider the establishment of a policy for the siting of industriali fuel reprocessing plants and related waste management facilities. Primary concern in these deliberations was given to the development of a practicabie poliey based on the need to restrict, in the interest of public health and safety, the quantities and mobility of the high-level radioactive wast stored on-site at fuel reprocessing plants. As a result of the studies, wiltich were conducted, and after discussion with the industry, a policy was exablished. Background information leading to establishment of this policy is discussed in detail in U.S. Federal Register Notice No. 35 FR 17530 dated November 14, 1970. Appended to it is a new regulation for incorporation intsis the Gode of Federal Regulations. The new regulation, "Appendix F, 10CFR Part 50", became effective on February $12,1971$.

In addition to the previously existing: regulations for the siting, licensing and operation of industrial nucleas facillities, the new regulation provides the following criteria for siting operating licensed fuel reprocessing and related waste management fixcilities. 
1. Reprosisping plants need not be located on federal land. utims:

2. High-level liquid waste inventory last be limited to that produced in prior ive years.

3. A11 high-level waste must be transferred in AEC-approved, dry, stable, solid form to a federal mepository no later than ten years following separation of fissioni products from the irradiated fuel.

4. The Federal Government will have whysical responsibility and industry financial responsibility for disposal of high-level waste.

5. Disposal of high-leve1. fission product waste material will be permitted only on land omned and controlled by the Federal Government.

6. A design objective for reprocessing plants shall be to facilitate decontamination and removal of all significant radioactive waste from the plant, prior to decommissioning.

Industrial fuel reprocessing and related waste management facilities currently under construction and being planned will conform to the new regulatory criteria. Modification of equipment and procedures will be required at the NFS plant, since this plant was constructed prior to establishment of the policy discussed above.

\section{Possible Future Technological Requirements}

In support of our commitment to reduce the release of radioactivity from U.S. nuclear facilities to the minimum practicable, we look forvard in the 1970's to increased research and ceweplopent of technology for the removal and containment of radioactivifty from plant effluents, particularly from the gaseous effluents. While retease to the environment of fission gases which results from current: operating practices is within a very small fraction of the internationalTy accepted enviromental limits, we feel that an adequate technological bas must be available in the not too distant future for the removal of these gases to high decontamination factors. As a result, the development ofi this technology has been defined as a firm objective of the AEC program for development of reprocessing technology for fast breeder reactor fuels. It is expected that this technology will find application in LWR fuel reprocessing plants as well.

\section{Conclusion:}

In conclusion, we are convinced that the U.S.A. now has a technically sound and economically competitive base capability for reprocessing LWR fuels from the growing nuclear power utility industry. Improvements in process equipment and procedures are expected in these plants in the next decade as additional experience is gained and more efficient economic modes of operation become apparent. Looking further into the future, we expect this industry to $r$ ise to the greater chall lenge of reprocessing the more advanced breeder reactor fuels by incorporating in these plants the required new technology which we are developing, or by building new facilities specifically designed for that purpose.. 


\title{
EXISTING AND PROJECTED PLANTS AND PROCESSES FOR THERMAL REACTOR FUEL RECOVERY: EXPERIENCE AND PLANS
}

\author{
E. E. Sinclair \\ Division of Reactor Development and Technology, \\ U. S. Atomic Energy Commission, Washington, D. C., U.S.A. \\ and contributing authors \\ (see attachment 1)
}

The status of existing and planned industrial nuclear-fuel reprocessing facilities in the U.S.A. is summarized. The technology utilized, innovative modifications in process technology and equipment, experience gained, and potential future technological requirements are discussed.

The first commercial facility, the Nuclear Fuel Services Plant at West Valley, New York, has successfully operated since April 1966. The process employs a shear-leach head end, a technology first applied in this plant, followed by Purex decontamination and separation of uranium and plutonium, and a final ion-exchange cycle for plutonium. Current plans are to increase plant capacity from $1 \mathrm{MT} /$ day to 2 to $3 \mathrm{MT} /$ day of light-water-reactor (LWR) fuel.

Construction of the General Electric (GE) Midwest Fuel Recovery Plant at Morris, Illinois, has been completed. The design is based on the GE "Aquafluor" process and has the capability, at $1 \mathrm{MT} /$ day, of recovering plutonium, uranium, and neptunium from LWR fuels. A mechanical head end provides for fuel disassembly, multirod shearing, and vibratory tray dissolution. A Purex cycle provides separation of uranium, plutonium, and neptunium from fission products. Partition is accomplished by anion exchange. The uranium stream is converted to $\mathrm{UO}_{3}$ and $\mathrm{UF}_{6}$ in fluidized-bed converters. A unique feature is the use of the fluorination portion of the fuel cycle to effect the final uranium decontamination. High-level wastes are converted to solids.

The Allied-Gulf Barnwell Nuclear Fuel Plant near Barnwell, South Carolina, is designed to reprocess $5 \mathrm{MT} /$ day of LWR oxide fuel. It is expected to be in commercial operation early in 1974. A mechanical chop-leach head end is coupled with basic Purex technology. Novel features include a unique semicontinuous dissolver design and utilization of centrifugal contactors and electrolytic reduction of plutonium in the extraction system.

The Atlantic Richfield Company (ARCO) plans to build a reprocessing plant near Leeds, South Carolina. The ARCO plant, with a design capacity of $6 \mathrm{MT} /$ day for LWR fuel, is expected to be in commercial operation by July 1976. Current plans are to use a chop-leach head end and Purex technology and include a capability for neptunium recovery.

A recently developed national policy on reprocessing-plant siting and waste disposal defines criteria for use in the U.S.A. 
Sinclair, Session 2.4, page 2

Attachment 1 (Sinclair, Session 2.4)

\begin{abstract}
A. R. Fritsch Gulf General Atomic, Inc. San Diego, California
\end{abstract}

W. H. Lewis

Nuclear Fuel Services, Inc. Wheaton, Maryland

L. S. Moody

General Electric Company

San Jose, California
K. R. Osborne

Allied Chemical Nuclear Products, Inc.

Florham Park, New Jersey

L. L. Zahn

Atlantic Richfield Hanford Company

Richland, Washington 